\title{
Presentation of Amthilati Book Volume 5 by Kiyai Haji Taufiqul Hakim (Analysis Book)
}

Paridatun Sumiharti \& Zarima Mohd Zakaria

To Link this Article: http://dx.doi.org/10.6007/IJARBSS/v11-i10/11500

DOI:10.6007/IJARBSS/v11-i10/11500

Received: 11 August 2021, Revised: 13 September 2021, Accepted: 30 September 2021

Published Online: 16 October 2021

In-Text Citation: (Sumiharti \& Zakaria, 2021)

To Cite this Article: Sumiharti, P., \& Zakaria, Z. M. (2021). Presentation of Amthilati Book Volume 5 by Kiyai Haji Taufiqul Hakim (Analysis Book). International Journal of Academic Research in Business and Social Sciences, 11(10), $1242-1253$.

Copyright: (c) 2021 The Author(s)

Published by Human Resource Management Academic Research Society (www.hrmars.com)

This article is published under the Creative Commons Attribution (CC BY 4.0) license. Anyone may reproduce, distribute, translate and create derivative works of this article (for both commercial and non-commercial purposes), subject to full attribution to the original publication and authors. The full terms of this license may be seen at: http://creativecommons.org/licences/by/4.0/legalcode

Vol. 11, No. 10, 2021, Pg. $1242-1253$

Full Terms \& Conditions of access and use can be found at http://hrmars.com/index.php/pages/detail/publication-ethics 


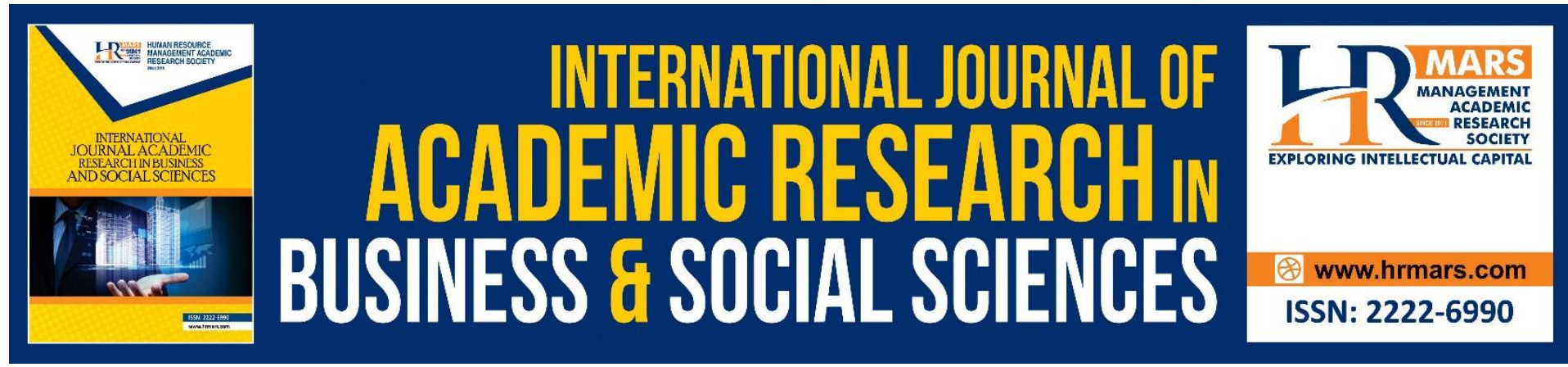

\title{
Presentation of Amthilati Book Volume 5 by Kiyai Haji Taufiqul Hakim (Analysis Book)
}

\author{
Paridatun Sumiharti \& Zarima Mohd Zakaria \\ University Sultan Idris Education University, 35900 Tg. Malim, Perak
}

\begin{abstract}
This study aims to find out the contents of the book Amthilati from the aspect, presentation. The study developed by the researcher utilizing a descriptive qualitative research method is a study made based on existing designs. Descriptive research aims to survey using library research instruments and documentation to collect data. The sample to be examined is the differentiation procedure which is the explanation of Nahwu Sarf into the language understood by the students, the ostensive procedure which is to use the object of action and situation to explain, the pictorial procedure which is to use pictures or other media, and the contextual procedure which is the abstract explanation: definition, numeration, substitution, metaphor and multiple contexts. Based on the research done, it is found that this book meets the requirements of the sample book allocated for Annatiqiina bigairiha (not native speakers) at the beginner level. Based on the research done, it is found that the book Amthilati is presented using a table which is then explained using the first language and Javanese language in Latin alphabets and Pegon alphabets (Arabic Jawi) that are appropriate to the culture of learning Arabic in Indonesia. The conclusion is that this book is in line with Mackey's theory which looks from the aspect of the presentation. The analysis of this study can be used as a guide and explanatory method needed for students who want to start a basic knowledge of Nahwu Șarf to understand the book of Turath.
\end{abstract}

Keywords: Presentation, Amthilati, Nahwu Șarf, Annatiqiina Bighairiha, Books for Beginners

\section{Introduction}

The spread of Islam along with the spread of Arabic, the glory and ability of Arabic in its role as the language of science, civilization and communication from pre-Islamic times to this day is proven (Al-Mubarrok, 1988). It cannot be denied that all sources of Islamic civilization which rely on the al-Qur'an and al-Sunnah and the works of 'al-Turath al-Is/ami written by the scholars' in the form of books that are trusted are in Arabic.

There are 2 categories of books according to their time; the first is called the classical books (al-kutub al-qadimah), the second is called modern books (al-kutub al-'ashriyah). The difference between the first and the second is the way of writing that does not have a stopping (waqaf), punctuation, classical and without vowels (Ismail, 1997).

Towards the goal of understanding these books, it is necessary to have an introductory book for not native speakers (Annatiqina bigairiha), because according to Hamid et al (2008) the ideal composition of Arabic books is a book developed based on 3 principles, namely: social 
principles culture, the principles of psychology, and the principles of language and education. Besides, the book as teaching material must fulfil 3 principles, namely: the relevant principle (suitability), the principle of consistency (continuity), the principle of sufficiency (fulfilling the will) (Rahman, 2018).

This book consists of 5 volumes of Amthilati, 1 volume of Qā'idatī, 1 volume of Khulāșah, 2 volumes of Tatimmah and 1 volume of Sharfiyah which these books mutually support one another. Amthilati volume 5 is the emergence of the Amthilati books, in the book, there is the practice of all the structure from the beginning and in it also contains the Pegon symbol, which gives meaning to the book with a typical Islamic boarding school-style meaning technique, both using Javanese, Sunda and others but written with several symbols that show certain meanings to understand the position, form (shigat), and meaning contained in a sentence or word from the point of view of Nahw science. These symbols are a summary in the process of giving the punctuation (I'rab) of the book. The goal is of course to make it easier for students to interpret a sentence briefly and also to help them learn Nahw science.

\section{Conceptual Framework}

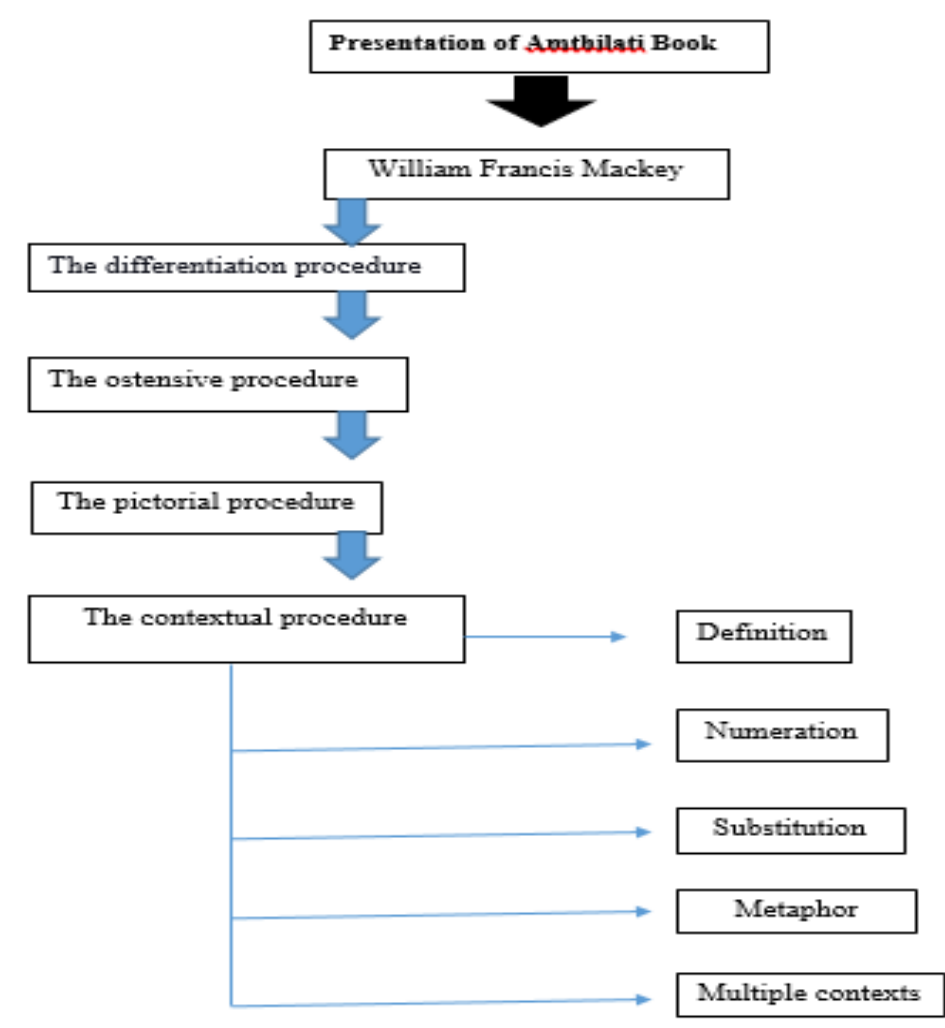

\section{Research Background}

According to Husein (2019) students in Indonesia are faced with linguistic structure books by scholars from Arab lands, the majority use Arabic as the main language and the language of explanation (syarah).

Likewise in the preparation of the introductory books for not native speaker to understand the classic books. Although the Arabic structure books are intended for novice students, because the culture of Arabic and Indonesian writing is different, students in Indonesia experience difficulties. Because the classic book is arranged according to: 
1. Starting from a verse while the learning culture in Indonesia starts with letters, words, then verses.

2. The classic book does not use standard punctuation marks such as dots, commas, colons and semicolons and others.

3. The stretch is too long.

4. The conversation is not well structured, that is, it is not distributed among the subheaders, sub-headers, and so on. So that it makes it difficult for the reader to distinguish between the punctuation and the details of the punctuation.

5. Form (shighat) is not put.

Looking at the problems and the process of achieving these goals, it is hoped that the Amthilati book will be able to be a solution to the problems faced considering that the Amthilati book was written for novice students to quickly understand Arabic principles to be able to read the classic book by selecting vocabulary, structure and exercises. the publication of the theme groups and the order of the books are accompanied by simple pictures, some typical Indonesian symbols (Pegon / Jawi), repetitive structures and the language of instruction using Indonesian and a scheduling scheme. This is considering the tendency of children to draw pictures, table schemes and easy summaries for beginner students (Mulyasa, 2008).

Amthilati volume 5, Khulāșah and Q $\bar{a}$ 'idatì volume 5 are adequate for this study because these books are considered to be the stem of the Amthilati book which was studied after passing Amthilati volumes one to four, so all the principles of chapters 1- 4 have been included in the examples. Amthilati book volume 5 where the Nahw and Sarf principles are introduced rather than this volume (Hakim, 2003).

\section{Literature Review}

According to Basit (2011) the characteristics of books to reach the potential of students, namely: First, the content must be based on the linguistic analysis of students, there need to be non-linguistic and socio-cultural aspects. Second, it is necessary to analyse how the culture and characteristics of students differ from Arab culture. Third, it is necessary to carry out an educational analysis, namely the adjustment of teachers to students and students to teachers, adjustment of age, ability, stage of knowledge about language and the tendency of students to learn languages.

Meanwhile, the presentation analysis procedure related to teaching Arabic, Mackey suggests 4 models, namely: First; differentiation procedure is a way of explaining a rule by translating the explanation in the learner's first language. Second, extensive procedures, this procedure uses action objects and situations to explain. Third, the pictorial procedure is to use pictures. Fourth, contextual procedures, are explanations that are abstract including: definition, numeration, substitution, metaphors and multiple contexts (Mackey, 1978).

\section{A. The Differentiation Procedure}

According to Asyrafi (2016), the differentiation procedure is a procedure used to explain the morphology and syntax of Arabic into a language that is understood by students.

To avoid the lack of understanding of the Arabic language structure. It is used to explain a rule by translating the explanation in the language of the learners. Because students who study in Islamic boarding schools and public schools come from many regions, each region has a different language, while the number of regional languages in Indonesia recorded by the 
Language Development Agency of the Ministry of Cultural Education reaches 652 languages (Ministry of Education and Culture/ Ministry of Education and Culture, 2017).

By following the 1945 Law, the books to be studied must also be explained into a unifying language as the language of instruction in teaching.

\section{B. Extensive Procedures}

This procedure uses action objects and situations to describe. In the book, it must provide instructions on how the vocabulary and sentence structure are explained to students, the book must present the same rules using tools and objects of action or follow to the teacher (Setyawan et al., 2018).

\section{Pictorial Procedure}

According to Setyawan et al (2018) the pictorial procedure is a procedure that uses images or other media, where the book contains simple pictures or complex images.

Contextual procedures

Contextual procedures are abstract explanations which include:

\section{Definition}

Definition Is a limitation or meaning, can also be interpreted as a word, phrase, or sentence that expresses the meaning, description, or main characteristic of a person, object, process or activity. The definition is also defined as a description of the meaning that serves to limit objects, concepts, and circumstances based on the time and place of a study (Widjono, 2007). Following the author of a book originating from the land of Java who has a tradition of defining classic books using the Pegon Language (Jawi's Arabic) letters which is a characteristic of learning Arabic in Indonesian Islamic boarding school, which the author attaches to the Khulāșah book. It is a characteristic that has been popular between the XVIII and XIX centuries. It is based on the works of theologian (Ulama) in Java in that century, namely the Pegon script, although it is almost extinct, it is still being developed by Indonesian scholars, including $\mathrm{KH}$ Taufiqul Hakim in his work (Syamsul, 1995).

In language, the word Pegon comes from the Javanese language, Pego which means "ora normal anggone ngucapake" or unusual in pronouncing (Kromopawiro, 1867). This description is caused by the number of Javanese words which are later written in Arabic and become complicated when spoken. Meanwhile, Pigeaud in Pudjiastuti (1994) affirms that Javanese texts written in Arabic are called Pegon texts, which have the meaning of something twisted. This naming is because the number of characters with Javanese characters is less than the Arabic script which is the principal pattern. It should be emphasized here why it becomes complicated, Pegoous and deviant because the standard Javanese language needs to be written in its script, namely the Javanese script (Syamsul, 1995).

Pegon script in this form is also often referred to as bald Pegon so that it needs more accuracy because in writing it does not use punctuation marks (vowels / shakal). Without thinking the understanding of the Pegon script which is characterized and the culture of the Javanese Islamic community, together with the entry of Islam in this corner of the archipelago has also given rise to praise for Islamic culture with the local community. They use Arabic letters (hijaiyah) also to write their language, such as Bugis in Sulawesi, Sunda in West Java, and Madura as well. Therefore, the Pegon script is an Arabic script that has been adapted to write Javanese or localities in the archipelago with expertise in using hijaiyah letters. Apart from 
the Pegon script, there are also Malay or Jawi script which is commonly used by Muslims in Sumatra, Kalimantan, Malaysia, Brunei, and Southern Thailand (Patani).

Apart from the Pegon script, the Latin script is also a peculiarity used in the writing of the Koran, it has no difference with the use of ordinary Latin characters. It has 26 letters. Differences will appear when the old spelling (spelling van Ophuijsen) is still used, namely some letters such as $\mathrm{dj}, \mathrm{j}$, oe, sj, tj, ch and the digit above (2) for the rephrase which was in effect since 1901. This spelling was later replaced by the republic spelling or the Soewandi spelling since 1947 so that the writing becomes j, y, u, sy, c, kh (James, 2003). Likewise, the writing of the Latin script is used to write Sunda. Some additions are made, such as the vowels é and eu. There is also a writing adjustment according to the sound of the sound in pronunciation of certain consonants that are rarely used in Sunda alphabetical order, such as: $f, q, v, x, z, k h$, sy (Tamsyah, 2001). Some of these consonants are usually written down into letters: $p, k, p, k s, j, h, s$.

\section{a. Numeration}

Numeration is the numbering contained in a book.

\section{b. Replacement}

That is how words can be replaced with other words. They mention or write several symbols or symbols that show certain meanings to understand the position, form, and the meaning contained in a verse or word from the point of view of Nahw science. These symbols serve as a summary of the process of interpreting the book. The purpose is to make it easier for students to interpret a sentence briefly and can also help them learn Nahw science

\section{c. Metaphor}

According to Wahab (1998_, metaphors are linguistic expressions that cannot be interpreted continuously from the symbols used, but rather than predictions that can be used by symbols or by the meaning intended by the language expression.

\section{d. Multiple contexts}

Are the various contents contained in his writings (Setyawan, et al., 2018)

\section{Methodology}

This study uses a library-based methodology, namely studies that do not involve activities in the field. This methodology is more mass-saving and does not require a high cost. Even though this method is limited, from the point of view of the edicts related to the study editorial, this study only relies on reference materials in the library. However, this methodology was felt to be the most suitable for conducting this study.

In this study, the reviewer will utilize qualitative study methods, according to Creswell (Patilimia, 2011) qualitative as an investigation process to understand social problems or human problems based on the creation of holistic images formed with words, reporting the informants' views in detail, and composing them. in a scientific setting. Qualitative according to Bryman (2008) is a study strategy that usually emphasizes words versus estimating the data collected and analyzed.

The study, which is supervised by this investigator, is a descriptive study or a study that is made based on the available fiction. Denzin and Lincoln (1994) argue that qualitative inquiry involves a variety of methods in a focused manner, including using a naturalistic approach to 
investigating a subject. Cresswell (1994) also defines that qualitative inquiry is a process of inquiry towards an understanding based on data collection methods commonly used when reviewing social problems.

While the study method used is the literature method. According to Ahmad Mazhab Ayob (1985), the method of study is a matter of how each objective or investigation is to be achieved. The study methodology is the collection of updated information and data relating to the review carried out. The method of study usually takes into account the aspects of choosing the study method, language learning theory, data collection procedures and data analysis procedures. Meanwhile, literature rules are the efforts made by the investigator to collect all information that is relevant to the problem or topic to be or is being researched. Can be obtained from journals, freelance studies, books, written or electronic sources (Roth, 1986)

A literature investigation is a type of investigation carried out by an investigator by collecting data from books, journals, books, articles and certain writings (Pohan, 2007). In the context of this investigation, the investigator uses these data to analyze the book of Amthilati. Sources of data in this investigation consist of: Primary data is the investigation data that is selected directly rather than the source that is specifically collected by the investigator to answer the investigation. (Yoman Kutha R, 2007). The primary data in this investigation are the Amthilati, Khulāșah and Q $\bar{a}^{\prime} i d a t i$ books. Secondary data is data that is used as a source of support in investigations that discuss the theme. generally in the form of evidence, notes or reports arranged in the form of documents. (Hadi, 2009). The secondary data in this investigation are books and scientific works that study the Amthilati book, the development of the content of teaching and other books that support this investigation. Collecting data in this investigation using documentation techniques.

Documentation is a method that is done by searching for data about cases or change permissible in the form of notes, transcripts, books, newspapers, magazines and so on. (Arikunto, 2000). Documents used in the form of writing or works. This technique is done by looking for materials that are relevant to the object being studied.

The analysis used in this investigation is Cresswell's model analysis, in which there are six stages in the data analysis process, namely: organizing and preparing the data to be analyzed; read and view all data; all data coding; use coding as material to create descriptions; connect between themes and provide interpretation and meaning about themes (Cresswell, 2015)

\section{Result and Discussion}

The differentiation procedure

In the Amatsilati, Khulāșah and Q'̄'idati books, the explanation of the structure uses Indonesian and Javanese. For more details, the following is an explanation of each book:

\section{a. Book of Amthilati volume 5}

The explanation of the linguistic structure in the Amthilati book volume 5 is found on the initial sheet of the discussion, some are placed on the upper and lower sections using Indonesian, then some examples are placed related to the structure discussed.

The explanations contained in the Amthilati book that the investigator found included the meaning of the structure, procedures/steps, provisions, parts, conditions, training instructions, how to read, additional notes.

For the contents to be easily understood, KH Taufiqul Hakim explained the meaning of Arabic vocabulary, sentences and structures in the book using Indonesian and Javanese. The 
Javanese language is put in the literal meaning of only, the rest of the verse explanations are in Indonesian. To define the Arabic structure.

After the definition is explained in Indonesian and Javanese, the writer presents the procedure for various things. The procedure includes how to make fi'il muḍāri '(mabni ma'lum and mabni Majhul) both fi'il muḍāri' whose additional letters are one or two or three, steps to search in a dictionary, procedures to determine fa'il dhomir and dhozir, steps -steps to write fi'il muḍāri', steps how to certify fi'il muḍāri', fi'il muḍāri 'which contains the illat letter in its $J$ fi'il which includes the nașab and jazem letters, terms and answers, how to make fi'il amar both consisting of three letters (original letters), one, two and three additional letters, defective fi'il amar (fa 'fi'il or fa' and lam fi'il in the form of illat ( حرف علة), all of that is explained in Indonesian.

To make it easier to carry out all procedures, the author puts Latin Arabic letters. Arabic letters are also often written in Latin Arabic letters such as: additional letters (ya, ta, nun, alif), letter fractions that will be searched for in the dictionary such as the word خرج written kha, $\mathrm{ra}, \mathrm{ja}$, and the titles of each sub chapter.

As for each part such as the shadow of a dot or comma which is specific to fi'il muḍāri ' such

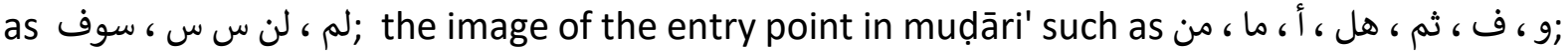

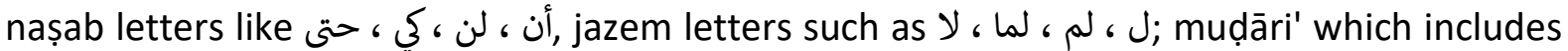

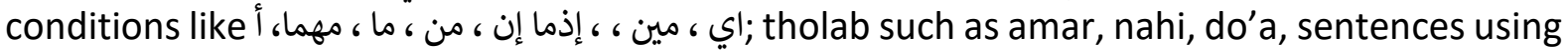

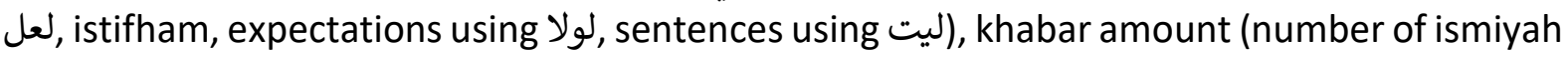
and number of fi'liyah). Each of these parts is described as one by one then each part is given an example.

In each example, the author of the book puts the reading rule on the upper row then reads it according to the original line, then repeats it twice, with the redaction of the verse "... without reading vowels ... becomes ... the origin ..."

The final presentation in the book of Amthilati is that additional notes are placed on the bottom row and always added with the word "important!" then the author explains the contents of the content in question. Usually, this supplementary note contains methods that are not commonly used / rarely used

\section{b. The Q'̄'idatī Book}

The language used to explain the summary of the structure is Indonesian but in a short language.

c. The Khulāșah Book

Amthilati book volume 5 is supported by the book Khulāșah it is summary of al-Fiyah Ibn Malik (Hakim, 2003). As a basis for the rule, there are 28 verses of Nadham summarized from Alfiyah for material volume 5 only. In the book each verse of Nadham is presented in the form of Nadham which is given the meaning of the Pegon script (Malay Arabic), the Javanese translation and the Indonesian translation, both literally or harfiyah, the meaning is written in Latin writing using Indonesian and Javanese meanwhile, the literal meaning is written using Jawi Arabic letters but in the Javanese language (Pegon Arabic). This is intended to facilitate understanding for beginner student, especially those who do not understand Javanese (originating from outside Java).

\section{Extensive procedures}

Presentation of material with an extensive procedure is how the book is described or in what kind of situation, the presentation of the book follows the instructions for use where that is 
how it should be done and what conditions, along with the instructions for use contained in the book.

a. The sign () contained in the Amthilati book is a sign that the header will be delivered, as well as providing sufficient information

b. Students are directed to read the example verse 2 times, the first reading is complete without stopping (waqaf) according to Nahwu, the second reading is stopping of according to a recitation

c. Students are asked to read the information underneath and read the basic verse by looking at the Khulāșah

d. How to read the verses starting from top right sorted down.

e. Dots and verses that are not sociable should not be filled in writing but filled in orally

f. If you are going to finish studying, then memorize the formulas and methods according to the material that has been taught

g. If you start learning again, repeat the method formula as needed

h. To find out the quality of writing, students give homework or are asked to write the existing material.

i. If students can memorize vocabulary, it is better memorized

2. Pictorial procedure

The pictorial procedure for the Amthilati book volume 5 uses schedules and symbols to present the material, the top schedule contains the structure, the middle section schedule contains examples and the bottom section contains an explanation of the structure, verses and verse pieces.

In the upper, middle and lower part of the schedule, there are several symbols as markers including:

a. Symbol $\Leftrightarrow$ : means the madly

b. Symbol: means the origin (origin of the word)

c. Symbol =>: means how to read it

d. Symbol: means the stop sign

e. Symbol means the marker of each important point

Those are some simple pictures that are placed in the Amthilati book volume 5, while in the Qā'idatī book it contains only, schedule and the Khulāșah only contains verses without any symbols and schedules.

\section{Contextual Procedure}

The contextual procedure is an abstract explanation including definition, numeration, substitution, metaphor and multiple contexts

\section{a. Definition}

The explanation of the definitions contained in the Amthilati book is found at the beginning of each chapter and the beginning of the contents, the explanation of the definition is written briefly with a literal meaning or what is known as a nominal definition. The definition or meaning of other languages is also found in the Khulāsah book, which is translated word-byword and interpreted by the Javanese Pegon language which is written in italics under the vocabulary, the following is the data found by investigators: 
Pegon writing in Javanese is not the same as Javanese which is written using Latin letters. The Arabic Pegon is used to give meaning to words, while the Javanese language in Latin is the general definition implied in verse.

\section{b. Numeration}

The numeration or numbering found in the three books is different

In the book Amthilati volume 5 begins with pages I-V (Roman numerals) which contain preface, prologue, appeals, and study instructions. Pages 1-45 contain material but at the beginning of each chapter, there is no page number placed. The numbering that is also listed in this book is the verse number of the verse which is placed under the sample row so that the process of finding a verse is easier.

The Qā'idatī book chapter 5 starts from pages 29-39 (excluding additional information). The pages and numbers in this book correspond to the Amthilati and Khulāșah books. Where "Hal" stands for the abbreviation of the page for Amthilati and "No" stands for the verse number of Khulāșah. In the first row, namely "hal", a page is placed that corresponds to the page in the Amthilati book, which is a page that only contains important principles, it does not include all forms of training, both training in giving lines, training in giving meaning and training in determining position. Whereas in the fourth lane is "No" or number stanza which serves as the key to finding poetry in the Khulāșah book.

The Khulāșah book which underlies the Amthilati book chapter 5 and Qā'idatī volume 5 starts from pages $8,15,32,34,35,36,43$ to page 51 . Where the verses start from verse 131-157 on page 43-51 (except the 146th stanza is not mentioned in Amthilati volume 5 and Qā'idatī chapter 5 ), then several verses are taken randomly such as stanzas no $23,24,47,96,97,101$, 102, 103, 104, 105 and 109.

\section{c. Replacement}

The replacement meant here is how to replace Arabic vocabulary with other languages. The investigator found that in the book of Amthilati volume 5, there was the symbolic language on certain positions and forms (shighat-shighat) found in the examples and practice sheets. The writing of this symbolic language is written under the vocab with an abbreviation of the particular vocab.

The following are the letters used and their meanings in Javanese and Indonesian:

1) The letter $\mathrm{p}$ : utawi / beginning (position mubtada ')

2) Letter $\dot{\tau}: k u /$ the (position khabar)

3) The letter ج: mongko / then (position is answering)

4) The letter $\mathbf{\text { : }}$ hale / in a state (position is hal)

5) The letter li: sopo / who indicates the subject/person (his position is fa'il aqil)

6) The letter ف: opo / what shows a subject that is not a person such as objects, masdhar, etc. (his position fail ghairu aqil)

7) The letter مف: ing / on, shows the object (its position is maful bih)

8) The letter نف: sopo / opo / who / what shows the substitute subject in a passive sentence specifically for the subject of naibul fa'il, in the form of people (the position is naibul fail)

9) The letter نف: sopo / opo / who / what indicates a substitute subject in the passive voice which is specifically for a non-person subject (his position is naibul fail ghairu aqil)

10) The letter مع: Sertane / along (his position as maf'ul ma'ah) 
11) The letter ن: kang / yang (position is na'at, isim that follows the word that is followed)

12) The letter ص: Kang / yang (his position as shilah, or a character sentence that falls after isim maushul for example الذي)

13) The letter مط: kelawan / with (the position is absolute maful)

14) Letter b: ingdalem / at (zhorof position)

15) The letter بu: Rupane / apparently 'turns out to be' (his position as badal)

\section{d. Metaphor}

Is figure of speech (majaz) that is used to explain or describe a thing by referring to other things that are considered to have characteristics similar to something or someone who wants to be described.

The investigator found majaz in the 3 books which are both located on the cover of the book of the back. It is a verse taken from the Khulāșah book.

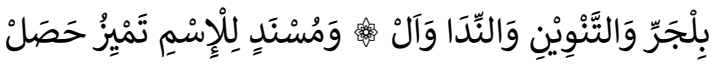

A high degree in the sight of Allah is obtained by: jar must submit and tawadlu', right intention to seek the pleasure of Allah, nida dhikr, Al thinking musnad ilaih with real faith.

e. Multiple Contexts

In terms of the plurality of contexts, in the 3 books, there is a plurality of contexts, namely in the form of Arabic, Jawi, Indonesian and Javanese.

\section{Conclusion}

The strengths of this book are very concise and clear. The use of sentences is very simple because these sentences function as patterns in tarqib verses of the Al-Qur'an and the book of Turath. The author gives the term magic words (spell) which contain a concise Nahwu-Sarf formulation and are still in the standard Nahwu-Șarf principle. With this "magic", the reader can apply it to the exercises that have been provided in this book so that it is easy to read, describe the structure of words as well as translate verses of the Al-Qur'an and the classic book because it is also supported by a simple dictionary containing frequently repeated vocab of Arabic in the al-Qur'an and the classic book.

Fulfilling the non-linguistic or sociocultural aspects, this is intended so that the approach, method, and presentation technique, as well as the material, is relevant to the conditions of students so that the book is suitable and useful.

\section{Acknowladgement}

There is no word more beautiful and more appropriate for the author to say, except the sentence of gratitude, for the completion of this thesis. A tiring work and requires extra patience to complete the writing of this investigation. Only because of His strength, guidance and guidance, finally, everything can be resolved

High appreciation goes to my principal supervisor, Dr Zarima Mohd Zakaria for his guidance, advice and patience so that this study can be completed. With his expertise, he helped guide the preparation of this study. I also thank the employer, the Sultan Idris Education University (UPSI)

Not to be forgotten, a single appreciation for my parents was addressed to my father Sumrahadi and my mother Fatimah and the family of relatives who kept praying and was the biggest motivation for me to prepare this thesis. 
Furthermore, my appreciation goes to the Governor of West Nusa Tenggara through the Education Development Institute (LPP) who has entrusted and provided the opportunity to study in the dream country since 2009.

Finally, appreciation to fellow members Arroyyah Dian, Fitri, Rizka, Karni, Mila H, Yuniar, Mila Septian and Hafizah who helped a lot and burning my spirit to finish this final project as soon as possible.

\section{References}

Syamsuddin, A. (2010) Metodologi Pembelajaran Bahasa Arab. Yogyakarta: Idea Press Yogyakarta.

Mulyasa, E. (2008). Menjadi Guru Profesional Menciptakan Pembelajaran Kreatif dan Menyenangkan. Bandung: PT Rosda Karya,

Hamid, F. A. (1987). Proses Belajar Mengajar Bahasa. Jakarta: Depdikbud.

Husein, M. (2019). Penerapan Metod Syawir Dalam Pembelajaran Nahw Șarf Di Perguruan Islam Pondok Tremas Pacitan Tahun Ajaran 2018/2019 (Doctoral dissertation, IAIN).

Inayatullah. (1976). Why We Learn The Arabic Language. Lahore: Ashraf Press.

Ismail, F. (1997). Paradigma Kebudayaan Islam: Studi Kritis dan Refleksi Historis, (Cet. ke-2). Yogyakarta: Titian Ilahi Press.

Mackey, W. F. (1978) Language Teaching Analysis. London: Longman

Misbah, M. (2006). Taufiqul Hakim "Amthilati" dan Pengajaran Nahw-Șarf. Insania: Jurnal Pemikiran Alternatif Kependidikan, 11(3), 389-407.

Nurrohmah, G. R. (2000). Theoretical challenges for distance education in the 21st Century: A shift from structural to transactional issues. International Review of Research in Open and Distance Learning, 1(1), June, 1-17.

Maran, R., \& Rafael. (2007). Pengantar Logika. Jakarta: PT Grasindo.

Nasution, S. (2009). Asas-Asas Kurikulum.Jakarta: Bumi Aksara

Hadi, S. (1995). Bahasa Arab dan Khasanah Sastra Keagamaan di Indonesia, Humaniora, II hlm. 87-95 Diadopsi dari Kitab Majmu' Syarat karya KH Saleh Darat dengan aksara Pegon halaman. Toha Putra: Semarang.

Wahab, A. (1998). Isu Linguistik Pengajaran Bahasa dan Sastra. Surabaya: Airlangga University Press.

Widjono. (2007). Bahasa Indonesia. Jakarta:PT Grasindo.

Zainal, A. (2011). Konsep dan Model Pengembangan Kurikulum (Konsep, Teori, Prinsip, prosedur, Komponen, Pendekatan, Model, Evaluasi dan Inovasi. (Bandung: PT Remaja Rosda Karya) 